Article

\title{
Revisiting the Inclusion-Moderation Thesis on Radical Right Populism: Does Party Leadership Matter?
}

\author{
Laurent Bernhard \\ Swiss Centre of Expertise in the Social Sciences, University of Lausanne, 1015 Lausanne, Switzerland; \\ E-Mail: laurent.bernhard@fors.unil.ch
}

Submitted: 30 September 2019 | Accepted: 27 January 2020 | Published: 5 March 2020

\begin{abstract}
This article reflects on the inclusion-moderation thesis, which asserts that parties from the radical right become like mainstream parties once they move from the opposition to government. This mainstreaming primarily occurs through the moderation of issue positions and the decline of populism. In this article, I focus on populism and consider the role of party leadership for government parties. I distinguish between traditional and managerial leadership. While traditional leadership employs an adversarial strategy toward mainstream parties, managerial leadership adopts an accommodative strategy. This article looks at three phases: 1) the opposition period; 2) in office under traditional party leadership; 3 ) in office under managerial party leadership. I expect that, compared to the second phase when the party is in office under traditional party leadership, levels of populism are higher during the opposition period and lower when it is in office under managerial party leadership. The empirical part of this article conducts a quantitative content analysis on the populist communication of the Geneva Citizens' Movement, a radical right party from Switzerland. The findings tend to support my theoretical argument.
\end{abstract}

\section{Keywords}

government participation; party leadership; populism; radical right; Switzerland

\section{Issue}

This article is part of the issue "Leadership, Populism and Power" edited by Cristine de Clercy (Western University, Canada).

(C) 2020 by the author; licensee Cogitatio (Lisbon, Portugal). This article is licensed under a Creative Commons Attribution 4.0 International License (CC BY).

\section{Introduction}

Over the last few decades, the radical right in Western Europe has managed to emerge, develop, and increase its electoral weight in numerous countries. Some of these parties have even entered coalition governments. The increased government radical right parties in governments has prompted scholars to explore the question of mainstreaming (Akkerman, de Lange, \& Rooduijn, 2016). The inclusion-moderation thesis states that radical right parties become more like mainstream parties once they participate in government. Apart from a moderation of issue positions, this expectation refers to a reduction in terms of populism. Regarding the latter, the state of the art reveals inconclusive findings. In this article, I propose focusing on the role of party leadership in order to examine the inclusion-moderation thesis in a more nuanced way. The main theoretical contribution of this article is the distinction between traditional and managerial party leadership of radical right parties in office. While traditional leadership employs an adversarial strategy toward mainstream parties, the latter favors an accommodative strategy. This article looks at three phases: 1 ) the opposition period; 2 ) in office under traditional party leadership; and 3) in office under managerial party leadership. When compared to the second phase when it is in office under traditional party leadership, I expect that the radical right's level of populism will be higher during the opposition period and lower when it is in office under managerial party leadership.

I illustrate my theoretical argument by focusing on the Geneva Citizens' Movement (MCG) from Switzerland. Located in the Canton of Geneva, this regional radical right party has rather successfully relied on continuous mobilization against cross-border commuters from neighboring France. I selected this case because the MCG 
has experienced the three phases of interest in chronological order in its short history so far. Indeed, it was first in the opposition (from 2005 to 2013, Phase 1), then in office under traditional party leadership (from 2013 to 2016, Phase 2), and finally in office under managerial party leadership (since 2016, Phase 3). Based on a quantitative analysis of the MCG's newspaper, I show that, compared to the second phase, where the party was in office under traditional leadership, the party relied more frequently on populism in the first phase when it was in the opposition and less so in the third phase where it was in office under managerial leadership. These results are in line with my theoretical argument.

The remainder of this article proceeds as follows. Section 2 develops the theoretical argument by proposing that the radical right relies on varying levels of populism depending on the phase it is in. Section 3 focuses on the MCG's trajectory by chronologically outlining the three main phases the party experienced since its foundation. Section 4 describes the documents selected for the empirical analysis as well as the construction of the indicators. Section 5 presents the findings of my investigation using both descriptive and inferential statistics. Finally, Section 6 briefly summarizes the key findings of this contribution and embeds them into a larger context.

\section{The Role of Party Leadership}

Over the last few decades, parties from the radical right have emerged, developed, and increased their electoral weight across Western Europe (Mudde, 2013). In addition to having firmly established themselves in the political landscape of a large number of countries, some of them even managed to enter national and subnational governments. Once considered political pariahs by mainstream parties, the radical right has increasingly emerged as a potential coalition partner in recent years (Biard, Bernhard, \& Betz, 2019). Some prominent examples include the government participation of parties such as the Austrian Freedom Party, the Finns, the Norwegian Progress Party, and the League in Italy.

The widespread inclusion of the radical right in governments, among other issues, has prompted scholars to question the concept of mainstreaming (Akkerman et al., 2016). According to the inclusion-moderation thesis (see Tepe, in press, for an overview of its original meaning), parties from the radical right should become more like mainstream parties once they move from the opposition to government. Scholars have begun to test this theoretical expectation by examining two key dimensions of mainstreaming: the moderation of issue positions and the decline of populism. In the case of Western Europe, it appears that the government participation of the radical right did not generally lead to its ideological moderation. However, there is evidence that it became more mainstream with respect to European integration issues (Akkerman et al., 2016).
As to populism (and more generally anti-establishment attitudes and behavior), no conclusive evidence has emerged from the few comparative studies so far (Akkerman et al., 2016; Albertazzi, 2009). This suggests that government participation does not always reduce the radical right's reliance on populism. In this context, the study by Albertazzi (2009) shows that, when in office, the radical right can exhibit behavior that is similar to its behavior while in the opposition and that it can resort to a division of labor between responsible government members and de facto oppositional party leaders. Based on these considerations, I expect that the strategies adopted by government parties of the radical right play a crucial role in the extent to which they resort to populism.

The following analysis will focus on the dimension of populism by highlighting the role of party leadership. I will discuss the radical right's level of populism by distinguishing between three phases: Phase 1) the opposition period; Phase 2) in office under traditional party leadership; and Phase 3 ) in office under managerial party leadership. As compared to Phase 2, I argue that the radical right exhibits higher levels of populism during Phase 1 and lower levels during Phase 3.

The academic literature identifies populism, authoritarianism (i.e., belief in a strictly ordered society, in which infringements of authority should be severely punished), and nativism (i.e., the view that the sensibilities and needs of the 'native-born' should be given absolute priority over those of newcomers) as major characteristics of the radical right (Mudde, 2007; Rooduijn, 2015; Rydgren, 2013). Populism considers society to be divided into two antagonistic groups: the vast majority of virtuous people and the elites that pursues its own interest (Mudde, 2004).

In the opposition period (Phase 1), it is reasonable to expect that radical right parties rely heavily on populism by mobilizing ordinary citizens around a common set of grievances and resentments that provide them with a sense of a shared identity as the genuine and authentic 'people' who are pitted against the elites in general and the government in particular (Betz \& Bernhard, 2019). The radical right typically accuses the elites of putting internationalism ahead of the nation and ahead of the interests of the 'people,' who are defined in ethnic terms (Mény \& Surel, 2000). The radical right claims that it represents the 'common sense' of ordinary people and that it will restore their voice, thereby promising that political decisions will become the true expression of the popular will.

Scholars have emphasized that radical right parties are frequently organized around a strong and internally uncontested leader (e.g., Taggart, 2000). Indeed, the radical right is currently the party family that is most often associated with personalistic parties (Schedler, 1996). Radical right parties are thus heavily dependent on their leader for conveying their populist messages. In order to draw the attention of the media and citizens, this leader must not fear intentionally relying on provocations that 
challenge the formal and informal rules of the democratic game.

Due to their pronounced populist mobilization, electorally successful radical right parties face a major internal challenge when sharing power with mainstream parties in office. Given that the radical right mobilizes ordinary citizens against established elites that they hold responsible for all their grievances, close and visible cooperation with mainstream parties may be seen as a betrayal of its core beliefs by substantial parts of its party members (Heinisch, 2003; Heinisch \& Mazzoleni, 2016). Unlike this traditional adversarial approach, more pragmatic party members may prefer to settle for policy compromise by pursuing a more accommodative strategy toward mainstream parties. This tension may become particularly visible when office holders take actions and make public statements that contradict the official positions of the party (Harmel \& Svåsand, 1993).

While the electoral growth in the opposition period typically builds around a strong leader that dominates the party, this may not be the case in the second phase. Once the radical party is in office and participates in government, it likely forms a second center of power, a managerial wing, which is articulated by the members of government (Mazzoleni, 1999, 2010). Within a radical right party that is in office, there may thus be a separation between the party leader on the one hand and the office holders on the other. Due to diverging party strategies, this setting may rapidly incite internal conflicts. The managerial wing may want to abandon the unconventional style and unpredictable behavior of the party leader and his/her entourage, thus preferring a more credible and trustworthy person at the head of the party who will put more emphasis on cooperating with mainstream parties. Hence, the period of government participation is likely to be marked by factionalism, which can lead to sharp conflicts and may ultimately even lead to a split that separates pragmatic from the more oppositional forces (Heinisch, 2003; Luther, 2011). A great deal of partyinternal coordination is thus required to cope with this challenge (Harmel \& Svåsand, 1993).

I will now argue that the level of populism displayed by radical right parties in office depends on which faction gains control of the party (for the sake of simplicity, I do not account for an intermediate variant, which refers to a power-sharing solution between the two factions, which could be labelled as 'dual leadership'). If the traditional figure and his/her entourage manage to continue to assume party leadership (Phase 2), then the radical right will rely on a pronounced degree of populism. This is due to the fact that it will basically maintain its adversarial strategy toward mainstream parties. However, it is expected that it will pursue a lower level of populism than during the opposition period (Phase 1). This is because the party leadership has to account for the wishes of the managerial wing (i.e., pragmatic forces in general and the government members in particular), at least to some degree.
I expect that there will be a greater reduction of populism if the managerial wing takes control of radical right parties in office (Phase 3). This can be attributed to the fact that the new leadership may want to abandon its transformative aspirations in order to detoxify its image as an unreliable party, thus becoming a more acceptable partner to mainstream parties. Rather than an ideological moderation, such a leadership change would entail a break with the initial adversarial approach directed against the political establishment in the name of the 'people.'

To summarize, I posit that the levels of populism by the radical right differ according to the aforementioned three phases. I expect that the highest level of populism occurs during Phase 1 , in opposition, followed by Phase 2, in office under traditional party leadership, and Phase 3 , in office under managerial party leadership. In other words, I expect that in Phase 2, in office under traditional party leadership, there will be an intermediate level of populism. Hence, the hypothesis states:

As compared to the phase when it is in office under traditional party leadership (Phase 2), the radical right's level of populism is higher during its time in opposition (Phase 1) and lower when it is in office under managerial party leadership (Phase 3).

\section{The Trajectory of the MCG}

This hypothesis will be tested using the case of a regional radical right party from Switzerland-the MCG. I decided to select this party because it has experienced the abovementioned three phases chronologically since its foundation in 2005. The first phase (until 2013) includes the MCG's opposition period during which it experienced a spectacular electoral ascent thanks to its traditional leader, Eric Stauffer. The second phase (from 2013 to 2016) started with the election of Mauro Poggia, a pragmatic member of the party, to the cantonal government. In this phase, the party remained under the traditional party leadership of Stauffer's entourage, while witnessing the rise of a managerial wing around Poggia. Despite diverging views over the party's strategy, the two factions managed to get along fine for three years. In 2016, however, a major dispute occurred during the party president elections leading Stauffer to quit the MCG. This event marked the beginning of the third phase, in which the managerial wing took control of the party.

Before addressing the MCG's trajectory, I would like to briefly provide some basic information about the party, given that it has received little scholarly attention so far. The MCG operates in the Canton of Geneva, whose territory is mostly surrounded by France. This peculiarity, coupled with the economic attractiveness of Geneva and the Agreement on the Free Movement of Persons between the European Union and Switzerland, have led to a sharp increase in cross-border commuters from neighboring France in recent years. This situation 
has provided the MCG with fertile ground for creating a successful populist mobilization. Using the slogan "Geneva and Genevans first," the party claims to be neither left nor right. Its cultural differentialism (Betz, 2004; Betz \& Johnson, 2004) manifests itself in a regional form by discriminating between people from Geneva, on the one hand, and cross-border commutes from France, on the other. However, the party's economic position is much more ambivalent. The MCG tends to embrace liberalism on financial policies by pleading for tax cuts and budgetary discipline. At the same time, it regularly supports an expansion of the welfare state, which distinguishes it from the Swiss People's Party, the largest radical right party in Switzerland (Bernhard et al., 2015; Mazzoleni, 2008).

\subsection{Opposition Period (Phase 1)}

The MCG was founded in June 2005 in the run-up to the cantonal elections. Two local politicians, Georges Letellier and Eric Stauffer, were the driving forces behind the party's establishment. Letellier, a native Frenchman, served as the party's first president. The MCG immediately met with success. In the October 2005 elections for the cantonal parliament, the party managed to surpass the electoral threshold of $7 \%$. The MCG made its entrance to the Grand Council by obtaining nine out of 100 seats. Considering that the party had only been founded four months earlier, and that it counted with no more than 30 members within its ranks, many observers described the MCG's $7.7 \%$ vote share as a sensation. During the campaign that preceded the vote, the party employed an aggressive tone. Indeed, it pledged to "wipe away cross-border commuters, the political establishment, and criminals" (Béguin, 2007, p. 125).

In 2006, a major quarrel erupted within the MCG. Letellier opposed the virulent anti-French xenophobia pursued by the party (Béguin, 2007, p. 129). This conflict led to his resignation and his decision to leave the party altogether. In the following years, Stauffer and some close associates took control of the MCG. George Jost (2006-2008), Stauffer (2008-2012), and Roger Golay (2012-2016) assumed party leadership in the following years. Stauffer not only established himself as the heart and soul of the party, but he also quickly became the enfant terrible of Genevan politics. Due to his extraordinary communication skills, he managed to become ubiquitous in the local media. To many inhabitants of Geneva, he hit the nail on the head by forcefully blaming crossborder commuters from France for their daily problems.

Stauffer attracted a great deal of attention by pointing out the malfunctioning of public companies. In part due to insider information, he targeted the Geneva Industrial Services (SIG), a state-controlled infrastructure company where he was a member of the Board of Directors. Stauffer denounced abuses in terms of executive pay and excessive electricity prices. As a result, the company was forced to scale back in both respects.
In 2008, Stauffer also succeeded in forcing the SIG to renounce importing waste from Naples on the grounds that this transaction would have led to a questionable relationship between the Camorra and the industrial services of the Canton of Geneva. In the Grand Council, Stauffer obtained abundant media coverage by repeatedly paralyzing parliamentary business through filibustering tactics and the submission of an excessive number of amendments. Additionally, cantonal MPs felt compelled to passing a weapons ban in the assembly, given that Stauffer carried a handgun in his everyday life.

In 2009, the party continued its electoral ascent. Thanks to a vote share of $14.7 \%$, it almost doubled its representation (17 MPs) in the Grand Council. The MCG succeeded in setting the agenda of the election campaign. In addition to using cross-border commuters from neighboring France as a scapegoat, the party focused on urban security issues. After a bloody fight between drug dealers occurred in the city of Geneva, members of the MCG were quick to capitalize on public discontent by taking to the streets. In the following years, Stauffer frequently continued to make headlines. In 2010, some of the MCG's billboards created diplomatic tensions between Switzerland and Libya in the context of a federal direct-democratic vote on the deportation of criminal foreigners. In 2012, Stauffer attracted a great deal of attention by throwing a glass of water onto a politician from the Liberals who had verbally provoked him in the Grand Council.

In 2013, the MCG emerged as the big winner of the cantonal elections. With $19.2 \%$ of the vote, the party obtained 20 seats in the Grand Council. The party probably benefitted from the fact that law and order issues ranked high in voters' minds, given that the murder of a young woman had occurred just one month before election day. In any case, the MCG stuck to its core issues during the campaign. Following the publication of an article in the party's newspaper, in which the president and the secretary described cross-border commuters as an "epidemic that is by far not eradicated" (Golay \& Baertschi, 2013), the International League against Racism and AntiSemitism urged the cantonal government to intervene. A video Stauffer posted on YouTube also caused quite a stir. The party leader stated that drug trafficking had established itself in Geneva under the helpless gaze of the judicial authorities.

\subsection{In Office under Traditional Party Leadership (Phase 2)}

In November 2013, the MCG experienced another major success. Mauro Poggia, a pragmatic member of the party, was elected to the seven-member government of the Canton of Geneva by taking a seat from the Greens. Poggia, an advocate who specialized in the defense of insured people, and formerly a member of the Christian Democrats, had joined the MCG in 2009 in the run-up to the cantonal elections. When in government, Poggia 
took over the newly created portfolio of Employment, Social Affairs, and Health. This allowed the MCG to exert some direct influence in terms of policy-making. The party's increased power was probably most visible in the labor market domain. Under the decisive pressure of the MCG, the Canton of Geneva had already introduced the so-called 'cantonal preference' legislation in 2012. This legislation prioritizes local unemployed people when there are job vacancies within the cantonal administration and state-controlled companies, such as public transport, the airport, the university hospital, and industrial services. In November 2014, Poggia announced that this scheme would be extended to the 250 organizations that receive subsidies from the Canton of Geneva (e.g., retirement homes, cultural institutions, and charities).

Detractors forecasted that the MCG would not succeed in reconciling Poggia's contained temper with Eric Stauffer's exuberance. At first glance, it hardly seemed imaginable that two such distinct characters would be able to work closely together. However, the so-called 'Poggia-Stauffer duo' harmonized well, at least in the beginning. Indeed, the fact that the MCG managed to remain united for three years was commonly attributed to successful internal coordination. The party relied on a division of roles between Stauffer's entourage and Poggia's growing number of followers. The latter were granted a discretionary degree of freedom from the official party line, which allowed the office holder to act responsibly and loyally to the other members of government from the mainstream parties. Stauffer and its entourage, for their part, basically remained responsive to their electorate by relying on their traditional, predominantly adversarial approach. The party continued to actively mobilize citizens against cross-border commuters by launching referendums and initiatives challenging the government's position, among others.

A local journalist observed that the MCG's two most prominent figures skillfully played on the same partition in public: "When Stauffer lights the fire, Poggia waters it down" (Le Temps, 2015). This division of roles also worked within the party, as illustrated at the 2015 annual party meeting when Poggia made the point that the economy would still need cross-border commuters even if all local unemployed people were hired. While party members greeted these words with sustained applause, not all of them were expressing approval for the same thing that evening. Some activists-undoubtedly adherents to the managerial wing-welcomed Poggia's pragmatic words, whereas supporters of Stauffer's more orthodox approach focused on the preferential treatment of local unemployed people, a key demand of the party since its existence (Le Temps, 2015).

\subsection{In Office under Managerial Party Leadership (Phase 3)}

The party's latent division turned into open conflict in Spring 2015, when the electoral fortune of the MCG took an unexpected turn toward the worst: The party failed to gain ground in local elections. As the party suffered its first set-back in its short history, internal rivalries quickly broke out. Several party figures publicly criticized Poggia for some of his statements and decisions, which they claimed had gone against the MCG's position. Others criticized Stauffer's authoritarian, egocentric, narcissistic, and even manipulative de facto leadership.

Most importantly, a major dispute with far-reaching consequences emerged as a result of the 2016 party president elections. In the framework of the annual party meeting, held in camera on 29 April, Ana Roch, a close associate of Poggia's, was elected by a margin of only one vote against Stauffer, the party's honorary president. Stauffers' defeat meant that his influence on the party's strategic decisions would decidedly diminish. Following that event, he decided to leave the party and to sit in the Grand Council as an independent. In September 2017, Stauffer announced the foundation of a new party, which several former members of the MCG joined. Its name, Genève En Marche! (GEM; Geneva on the Move!), was reminiscent of Emmanuel Macron's successful campaign to become French president.

It is worth noting that the MCG did not change its ideological profile after Stauffer's departure. Indeed, the party program has remained the same. Pundits simply observed that the MCG turned slightly to the left on economic issues. This was most visible in the domains of public finances and in the defence of the civil servants' interests. Without its enfant terrible, the party experienced a marked loss in media attention. This loss, together with the fact that three radical right parties competed for citizens' votes, did not bode well for the 2018 cantonal elections. As expected, the MCG experienced a resounding defeat. With a vote share of only $9.4 \%$, the party lost nine of its 20 seats in the Grand Council. Party figures could at least take comfort in the fact that the MCG fared better than its direct competitors from the Swiss People's Party (7.3\%) and GEM (4.1\%). As the latter failed to pass the threshold into the cantonal parliament, Stauffer announced the dissolution of the newly created party on Election Day. In addition, Poggia was comfortably re-elected to the Council of States.

Despite the MCG's electoral backlash, Roch managed to keep the party presidency in 2018. After her re-election, she declared that after two difficult years, during which the credibility of the MCG nevertheless increased among the other parties, the party had to pursue a strategy of openness and stability (Bretton, 2018). The party maintained this accommodative strategy under Francisco Valentin, the current party leader who was elected in 2019.

\section{Data and Operationalization}

The empirical part of this article is based on a quantitative content analysis of the MCG's party newspaper Le Citoyen (The Citizen). I chose this source as it is the 
only type of document that proved to be available for a period that encompasses the three phases being analyzed. The party distributes this publication among its members and to a broader audience at irregular intervals through canvassing activities and direct mailings, especially in the run-up to elections and direct-democratic votes. The number of issues per year ranges from one to four. This empirical investigation encompasses a period of almost ten years and includes 25 newspapers published by the MCG between September 2008 and February 2018. I gathered these documents from the Library of Geneva, the long-serving party secretary as well as from the MCG's website. However, I must note that I failed to collect at least three editions. Indeed, the first editions of Le Citoyen that were published before September 2008 do not appear in this investigation, nor do the newspapers from Spring 2010 and Spring 2012. Among the available documents, I selected articles that comprehensively address a given political issue at the cantonal or federal level. As a result, the number of articles included in this study is 167 .

The dependent variable of this study, populism, was operationalized using indicators based on Mudde's (2004, p. 543) influential definition. This definition views populism as an ideology that considers that society is separated into two homogeneous and antagonistic groupsthe pure people versus the corrupt elites-and that postulates that the will of the former must always prevail. While conceived as an ideology, it is now widely accepted among scholars that populism manifests itself in the discursive patterns of political actors (Hawkins \& Rovira Kaltwasser, 2019; Jagers \& Walgrave, 2007). In this manifestation, political communication can be analyzed to empirically capture populism (Aalberg, Esser, Reinemann, Strömbäck, \& de Vreese, 2017). In other words, this analysis proposes examining the extent to which political actors appeal to the people, denigrate the elites, emphasize the antagonism between these two groups, and call for popular sovereignty.

In order to measure populist communication, I account for the four core elements of Mudde's definition: i.e., 1) people-centrism; 2) anti-elitism; 3) calls for popular sovereignty; and 4) the antagonistic relationship between people and elites (see Bernhard, 2017). The content analysis consists of an assessment at the article level. For each of the four populist components of interest, a dichotomous indicator is utilized. More specifically, I employ the following coding criteria. People-centrism is coded as ' 1 ' if a given political actor portrays the people (or functional equivalents such as 'the population,' 'the citizens,' or 'Genevans') as a homogeneous unity. Regarding anti-elitism, the value of ' 1 ' is assigned if actors, such as the government in its entirety or the business community as a whole, are characterized in a fundamentally negative manner. As to popular sovereignty, demands for more power to the people, or the rejection of a loss of the people's power, take the values of '1.' Finally, the antagonistic relationship between people and elites are coded as ' 1 ' if there are statements that highlight a sharp conflict or an insurmountable clash of interests between people and elites. The coding work was carried out by a native French speaker. A separate reliability test was performed, which was based on 56 randomly selected articles (i.e., roughly a third of the total number), and its main result turned out to be satisfactory (the combined Cohen's Kappa amounts to 0.86).

When applying this coding scheme, it appears that the MCG most frequently made use of demands for people-centrism. This indicator proved to be present in slightly more than every third newspaper article (0.34). Indications of anti-elitism were apparent in one out of five documents (0.19), while antagonistic statements (0.11), and demands for popular sovereignty (0.08) turned out to be far less pervasive.

As a reviewer rightly pointed out, a multiplication of these four indicators is indicated from a theoretical point of view. In line with Mudde and Rovira Kaltwasser (2013, p. 151), it appears obvious to argue that all indicators need to be present in order to qualify as populism. However, such an encompassing co-occurrence was only the case in 19 out of the 167 articles included in this analysis. Due to this low level of variation, it was impossible to estimate the multivariate models presented in Section 5.2. Therefore, I decided to opt for an additive aggregation method, provided that the four populism indicators form a single dimension. To verify the dimensionality question, I rely on the Mokken scale analysis, a hierarchical scaling method that assumes the presence of an underlying latent attribute, which is represented by a set of observable items (van Schuur, 2003). Table 1 shows that the four populism indicators tend to occur together. Given that these indicators form a strong hierarchical scale (Loevinger's H coefficient amounts to 0.56 ), it is indicated to construct a composite measure by adding the four items. The populist communication index (PCI) thus ranges from 0 to 4 , with a mean score of 0.72 and

Table 1. Mokken scale analysis of the populism indicators $(\mathrm{N}=167)$.

\begin{tabular}{lcc}
\hline & Share of documents in which indicator is present & H-coefficient (scalability, maximum $=1$ ) \\
\hline People-centrism & 0.34 & 0.57 \\
Anti-elitism & 0.19 & 0.51 \\
Antagonism & 0.11 & 0.58 \\
Popular sovereignty & 0.08 & 0.58 \\
Scale & & 0.56 \\
\hline
\end{tabular}


a substantial variance across the articles under investigation (s.d. = 1.05).

Regarding the independent variable, I assigned the 167 selected articles to one of the three phases of interest. Based on the dates of publication, this resulted in the construction of three dummy variables. Eightyfive articles refer to the opposition period (Phase 1), as they were published before the election of Poggia to the Council of States of Geneva, 34 articles concern the phase of government participation under traditional party leadership, which lasted from December 2013 to April 2016 (Phase 2), and 48 articles cover the phase of the party in office under managerial party leadership (Phase 3).

With respect to the control variables, I propose accounting for the influence of issue domains, campaigns, and authorship. All indicators are dichotomous in nature. The classification of issue domains relies on the work of Kriesi et al. (2008). The economic dimension includes economic policies, welfare state issues, and finances. In contrast, topics related to cultural liberalism, European integration, education, immigration, the army, and security fall under the cultural dimension. In addition, there is a residual category of issues that cannot be clearly assigned to either of these two domains (i.e., ecology, institutional reforms, and infrastructure). With respect to the campaigns, I separately account for election contexts and direct-democratic votes. For the former, articles published within the last eight weeks before election day are considered to belong to the campaign period in the case of federal or cantonal elections. For the latter, newspaper articles take the value of ' 1 ' if they deal with a referendum or an initiative that was submitted to the ballot either at the federal or at the cantonal level. As far as authorship is concerned, I distinguish between the individual and the collective level. The articles signed by individuals are coded as ' 1 ' and editorial contributions are coded as ' 0 .'

\section{Empirical Analysis}

\subsection{Descriptive Statistics}

Among the three phases considered here, the highest mean $\mathrm{PCl}$ level ( $\mathrm{M}=1.00$ ) occurs during Phase 1 (i.e., the opposition period). In contrast, the lowest level $(M=0.27)$ appears in Phase 3 (i.e., in office under managerial party leadership). The difference is considerable given that the party played the populist card almost four times less frequently than in the first phase. In Phase 2 (i.e., in office under traditional leadership), the level of the MCG's ( $M=0.67$ ) populist communication is between that of Phase 1 and Phase 3. These descriptive figures are thus in line with the hypothesis.

I now briefly present some descriptive statistics pertaining to the control variables. At first glance, it seems that levels of populist communication do not vary much according to issues. When looking at the level of issue domains, it turns out that from 2008 to 2018 , the MCG did not rely on cultural populism more frequently than on economic populism ( $\mathrm{PCl}$ of 0.70 vs. 0.68 ), thus confirming previous research (Bernhard, 2017). Apart from that, the average $\mathrm{PCl}$ level for the residual issue category is 0.85 . When deconstructing the populist communication of the MCG for each main category, the party excels on a single issue. On the cultural dimension, this issue is immigration ( $M=1.33$ ), with a focus on crossborder commuters. In the economic domain, the highest score is attained for economic policies ( $M=0.95)$. In this respect, the MCG frequently relies on populist statements when addressing the maladministration of state-controlled companies. As to the residual category, the party frequently employs populist appeals on institutional reforms ( $M=1.18)$ above all else. This communication occurs on various isolated topics (e.g., extending direct-democratic rights, fighting lobbyism, and protecting the competences of the Canton of Geneva within the Swiss Confederation).

In terms of the campaign context, the distinction between election and non-election periods does not seem to influence the MCG's degree of populist communication ( 0.65 vs. 0.79 ). However, the articles that relate to direct-democratic votes achieve somewhat higher levels on the $\mathrm{PCl}$ than the remaining ones (0.92 vs. 0.65). Authorship, for its part, does not seem to matter. Newspaper articles signed by MCG party members are only slightly more populist than the editorial contributions (0.82 vs. 0.68$)$. When I also examine the various authors of the articles under investigation, it becomes obvious that Stauffer outclasses the remaining party figures in terms of populist communication. His average $\mathrm{PCl}$ score is 2.00 . The remaining individuals who wrote at least five articles attained the following $\mathrm{PCl}$ scores: Stauffer is followed by François Baertschi (1.29), Roger Golay (0.85), and Mauro Poggia (0.43). It is worth noting that the articles authored by the remaining individuals display very low levels of populist communication (0.18).

\subsection{Inferential Statistics}

In order to test whether the aforementioned descriptive patterns stand up to a multivariate analysis, I rely on ordered probit regressions. The results on the phases presented in Table 2 tend to support the hypothesis. As is visible from the first model, there is evidence that the MCG relied on populist communication more frequently during its initial opposition period (Phase 1) than when it assumed office under traditional party leadership (Phase 2). In addition, the significative negative coefficient for Phase 3 indicates that the party adopted lower levels of populist communication when it was in office under managerial party leadership compared to Phase 2, the reference category. These findings suggest that the second phase was characterized by an intermediate level of populism, which is in line with my theoretical argument. However, there is a caveat. Unlike the coefficient 
Table 2. Ordered probit regression model explaining the MCG's levels of populist communication.

\begin{tabular}{|c|c|c|}
\hline & Model I & Model II \\
\hline $\begin{array}{l}\text { Opposition period } \\
\text { (Phase 1) }\end{array}$ & $\begin{array}{l}0.504^{* *} \\
(2.04)\end{array}$ & $\begin{array}{l}0.499 * * \\
(2.02)\end{array}$ \\
\hline $\begin{array}{l}\text { In office under managerial } \\
\text { party leadership (Phase 3) }\end{array}$ & $\begin{array}{l}-0.620 * \\
(-1.94)\end{array}$ & $\begin{array}{l}-0.108 \\
(-0.27)\end{array}$ \\
\hline Economic issues & $\begin{array}{l}-0.048 \\
(-0.22)\end{array}$ & $\begin{array}{l}0.129 \\
(0.54)\end{array}$ \\
\hline Other issues & $\begin{array}{l}0.273 \\
(1.08)\end{array}$ & $\begin{array}{r}0.196 \\
(0.77)\end{array}$ \\
\hline Election context & $\begin{array}{l}0.149 \\
(0.74)\end{array}$ & $\begin{array}{l}0.056 \\
(0.27)\end{array}$ \\
\hline Direct-democratic vote & $\begin{array}{l}0.317 \\
(1.53)\end{array}$ & $\begin{array}{c}0.342 \\
(1.63)\end{array}$ \\
\hline Individual author & $\begin{array}{l}-0.124 \\
(-0.59)\end{array}$ & $\begin{array}{l}-0.050 \\
(-0.24)\end{array}$ \\
\hline Phase $3 \times$ economic issues & & $\begin{array}{l}-0.971 * * \\
(-2.00)\end{array}$ \\
\hline Cut 1 & $\begin{array}{l}0.422 \\
(1.46)\end{array}$ & $\begin{array}{c}0.478 \\
(1.64)\end{array}$ \\
\hline Cut 2 & $\begin{array}{l}1.310 * * * \\
(4.33)\end{array}$ & $\begin{array}{l}1.377^{* * * *} \\
(4.50)\end{array}$ \\
\hline Cut 3 & $\begin{array}{l}1.812 * * * \\
(5.62)\end{array}$ & $\begin{array}{l}1.884^{* * *} \\
(5.78)\end{array}$ \\
\hline Cut 4 & $\begin{array}{l}2.147^{* * *} \\
(6.30)\end{array}$ & $\begin{array}{l}2.221 * * * \\
(6.45)\end{array}$ \\
\hline $\begin{array}{l}N \\
\text { Pseudo } R^{2}\end{array}$ & $\begin{array}{r}167 \\
0.062\end{array}$ & $\begin{array}{c}167 \\
0.073\end{array}$ \\
\hline
\end{tabular}

Notes: ${ }^{*} p<0.10,{ }^{* *} p<0.05,{ }^{* *} \mathrm{p}<0.01 ; \mathrm{z}$-values in brackets. Reference groups: in office under traditional party leadership (Phase 2 ) and cultural issues (for issue domains).

of Phase 1, the one of Phase 3 narrowly misses the $5 \%$ error level normally used in regression estimations. In other words, the difference in populism levels between Phase 2 and Phase 3 is rather weakly secured from a statistical point of view.

I now comment on the influence of the control variables. The model confirms that the party does not more frequently resort to populism on economic issues than on cultural ones. At the level of single issues, further analyses (not shown here) reveal that the populist rhetoric of the MCG tends to prevail when immigration, institutional reforms, and economic issues are at stake. With respect to campaigns, electoral periods are not found to increase the party's reliance on populist appeals. The same holds true for direct-democratic votes, thus contradicting the impression obtained from the descriptive analysis. Finally, the party's level of populist communication does not prove to be related to authorship. Hence, articles signed by individuals do not differentiate them- selves from editorial contributions. Additional estimation models also accounted for individual party figures (i.e., Eric Stauffer, Roger Golay, François Baertschi, and Mauro Poggia). However, no single coefficient turned out to be significant. The absence of a positive finding at the individual level supports the conclusion that the MCG's level of populist communication primarily depended on the phase it was in during its short history.

Finally, a reviewer suggested testing the interaction between issue domains and the third phase. The rationale for this idea stems from the fact that the MCG is said to have moved slightly to the left on economic issues since the managerial wing took over party leadership (see Section 3.3). In the second model in Table 2, the significant negative coefficient of the interaction term between economic issues and Phase 3 shows that the party's decline in populist communication during Phase 3 was particularly discernible on economic issues. 


\section{Conclusion}

Over the last few decades, several parties from the radical right have managed to enter national and subnational governments in Western Europe. Inspired by the inclusion-moderation thesis, this article has examined the mainstreaming of the radical right in office. Given that the state of the art has found that government participation does not generally lead the radical right to become less populist, I have proposed a theoretical refinement by adding the role of leadership in government parties. The main contribution of this article is its distinction between traditional and managerial party leadership. The former is characterized by an adversarial strategy toward mainstream parties, while the latter favors an accommodative strategy. I hypothesized that, compared to the second phase when the radical right is in office under traditional party leadership, levels of populism are higher during the opposition period and lower when it is in office under managerial party leadership.

To empirically illustrate this theoretical argument, this article examines the case of the MCG, a regional radical right party from Switzerland that has continuously pursued a populist mobilization against increasing numbers of cross-border commuters from neighboring France. Based on a quantitative content analysis of the party newspaper, I examined the three main phases of the MCG's trajectory, i.e., initial opposition period (Phase 1), in office under traditional leadership (Phase 2), and in office under managerial party leadership (Phase 3). As compared to Phase 2, the MCG tended to rely more frequently on populist appeals during Phase 1 and much less so during Phase 3 This pattern is in line with my hypothesis. This contribution suggests that the MCG's decline in populism is not only attributable to government participation, but also to the party-internal transfer of power from the traditional leader to the managerial wing, whose representatives subsequently adopt a more pragmatic strategy.

A limitation of this study stems from its sole use of the MCG's newspaper, which left aside other valuable sources such as press releases, the paid media, and social media. More reliable results would emerge from an analysis encompassing several communication channels. A reviewer highlighted another inferential challenge related to the MCG's newspaper. Given that the party mainly seems to use Le Citoyen as a mobilization tool in the runup to elections and direct-democratic votes, it may be the case that levels of populism negatively depend on party size. This expectation hinges on the idea that larger parties may be incentivized to reduce their populist communication, since they have to appeal to a broad and therefore heterogeneous voter base. Due to the fact that the MCG has continuously increased its electoral strength in the period under investigation, it is difficult to account for this factor in this empirical analysis. However, the party's recent electoral set-back offers an opportunity to examine this alternative explanation in the future.
Given that the empirical part of this article limits itself to a single party, some caution about the generalizability of the main conclusions are in order. In addition to the peculiarities of the Swiss context (Mazzoleni, 2016), there is a need to more thoroughly consider the role of government participation and party leadership in the populism of radical right parties across Western Europe. Hence, it is fundamental that more research follow on radical right parties that have experienced the three phases of interest. It would be particularly stimulating to conduct comparative research, as such contributions could focus on contextual differences. For instance, it could be possible that the radical right reduces its level of populism before entering government in countries where this party family has traditionally faced a cordon sanitaire (i.e., a commitment by mainstream parties to exclude the radical right from coalition governments) in order to detoxify its bad image.

In addition, I would like to highlight that this theoretical framework can be applied to populist parties of any ideological stripe. Researchers may particularly seek to expand their focus to the radical left, a party family that nowadays also tends to rely heavily on populism (Bernhard \& Kriesi, 2019). An empirical examination could focus on Syriza in Greece and Podemos in Spain, as these two parties have managed to participate in government. This would enable scholars to analyze whether the radical right and the radical left differ in their reliance on populism once in office. Finally, unconventional populists would represent another fascinating subject of investigation. This applies, above all, to the Five Star Movement from Italy. It is worth noting that this case is particularly relevant when considering the role played by party leadership. In addition to the traditional leadership under Beppe Grillo, a managerial wing has emerged around Luigi di Maio since the party's entrance into government at both the national and subnational level.

\section{Acknowledgments}

The author would like to thank the 'thinkers and drinkers' of the GREC Research Unit of the Institute of Political Science at the University of Lausanne (especially Anke Tresch, Anna Herczeg-Brayer, Baptiste Dufournet, Evgeniya Shtyrkova, Gian-Andrea Monsch, Jan-Erik Refle, Lionel Marquis, and Lukas Lauener), Grégoire Yerly, Oscar Mazzoleni, the editorial team at Politics and Governance as well as Cristine de Clercy, and the three anonymous reviewers for their helpful comments.

\section{Conflict of Interests}

The author declares no conflict of interests.

\section{References}

Aalberg, T., Esser, F., Reinemann, C., Strömbäck, J., \& de Vreese, C. (2017). Populist communication in Europe. 
New York, NY: Routledge.

Akkerman, T., de Lange, S. L., \& Rooduijn, M. (2016). Radical right-wing parties in Europe: Into the mainstream? London: Routledge.

Albertazzi, D. (2009). Reconciling 'voice' and 'exit': Swiss and Italian populists in power. Politics, 29(1), 1-10.

Béguin, J. (2007). L'extrême droite genevoise: Des origines à nos jours [Geneva's radical right: From its origins to today]. Yens-sur-Morges: Cabédita.

Bernhard, L. (2017). Three faces of populism in current Switzerland: Comparing the populist communication of the Swiss People's Party, the Ticino League, and the Geneva Citizens' Movement. Swiss Political Science Review, 23(4), 509-525.

Bernhard, L., \& Kriesi, H. (2019). Populism in election times: A comparative analysis of 11 countries in Western Europe. West European Politics, 42(6), 1188-1208.

Bernhard, L., Kriesi, H., \& Weber, E. (2015). The populist discourse of the Swiss People's Party. In H. Kriesi \& T. Pappas (Eds.), European populism in the shadow of the Great Recession (pp. 123-137). Colchester: ECPR Press.

Betz, H.-G. (2004). La droite populiste en Europe: Extrême et démocrate? [The populist right in Europe: Extreme and democratic?]. Paris: Autrement.

Betz, H.-G., \& Bernhard, L. (2019). Conclusion. In B. Biard, L. Bernhard, \& H.-G. Betz (Eds.), Do they make a difference? The policy influence of radical right populist parties in Western Europe (pp. 273-288). London: ECPR Press.

Betz, H.-G., \& Johnson, C. (2004). Against the currentStemming the tide: The nostalgic ideology of the contemporary radical populist right. Political Ideologies, 9(3), 311-327.

Biard, B., Bernhard, L., \& Betz, H.-G. (2019). Do they make a difference? The policy influence of radical right populist parties in Western Europe. London: ECPR Press.

Bretton, M. (2018, May 31). Un MCG divisé réélit Anna Roch à sa présidence [A divided MCG re-elects Anna Roch as its president]. Tribune de Genève.

Golay, R., \& Baertschi, F. (2013, August). L'épidémie de frontaliers n'est de loin pas éradiquée [The epidemic of cross-border commuters is by far not eradicated]. Le Citoyen.

Harmel, R., \& Svåsand, L. (1993). Party leadership and party institutionalization: Three phases of development. West European Politics, 16(2), 67-88.

Hawkins, K. A., \& Rovira Kaltwasser, C. (2019). Introduction: The ideational approach. In K. A. Hawkins, R. E. Carlin, L. Littvay, \& C. Kaltwasser (Eds.), The ideational approach to populism: Concept, theory and analysis (pp. 1-24). London: Routledge.

Heinisch, R. (2003). Success in opposition-Failure in government: Explaining the performance of right-wing populist parties in public office. West European Politics, 26(3), 91-130.

Heinisch, R., \& Mazzoleni, O. (2016). Understanding pop- ulist party organization: The radical right in Western Europe. Basingstoke: Palgrave Macmillan.

Jagers, J., \& Walgrave, S. (2007). Populism as political communication style: An empirical study of the political parties' discourse in Belgium. European Journal of Political Research, 46(3), 319-345.

Kriesi, H., Grande, E., Lachat, R., Dolezal, M., Bornschier, S., \& Frei, T. (2008). West European politics in the age of globalization. Cambridge: Cambridge University Press.

Le Temps. (2015, April 8). Le duo Stauffer-Poggia: Pierre angulaire d'une stratégie [The Stauffer-Poggia duo: The cornerstone of a strategy]. Le Temps. Retrieved from https://www.letemps.ch/suisse/duostaufferpoggia-pierre-angulaire-dune-strategie

Luther, K. R. (2011). Of goals and own goals: A case study of right-wing party strategy for and during incumbency. Party Politics, 17(4), 453-470.

Mazzoleni, O. (1999). La Lega dei Ticinesi: Vers l'intégration? [The Ticino League: Toward integration?]. Swiss Political Science Review, 5(3), 79-95.

Mazzoleni, O. (2008). Nationalisme et populisme en Suisse: La radicalisation de la 'nouvelle' UDC [Nationalism and populism in Switzerland: The radicalization of the 'new' Swiss People's Party] (2nd ed.). Lausanne: Presses Polytechniques et Universitaires Romandes.

Mazzoleni, O. (2010). Personal leadership and party organization in a changing environment: The case of the Lega dei Ticinesi. Paper presented at the 60th PSA Annual Conference, Edinburgh, Scotland.

Mazzoleni, O. (2016). Staying away from the mainstream: The case of the Swiss People's Party. In T. Akkerman, S. L. de Lange, \& M. Rooduijn (Eds.), Right-wing populist parties in Western Europe: Into the mainstream? (pp. 252-275). London: Routledge.

Mény, Y., \& Surel, Y. (2000). Par le peuple, pour le peuple: Le populisme et les démocraties [By the people, for the people: Populism and democracies]. Paris: Fayard.

Mudde, C. (2004). The populist zeitgeist. Government and Opposition, 39(4), 542-563.

Mudde, C. (2007). Populist radical right parties in Europe. Cambridge: Cambridge University Press.

Mudde, C. (2013). Three decades of populist radical right parties in Western Europe: So what? European Journal of Political Research, 52(1), 1-19.

Mudde, C., \& Rovira Kaltwasser, C. (2013). Exclusionary vs. inclusionary populism: Comparing contemporary Europe and Latin America. Government and Opposition, 48(2), 147-174.

Rooduijn, M. (2015). The rise of the populist radical right in Western Europe. European View, 14(1), 3-11.

Rydgren, J. (2013). Class politics and the radical right. London: Routledge.

Schedler, A. (1996). Anti-political-establishment parties. Party Politics, 2(3), 291-312. 
Taggart, P. (2000). Populism. Buckingham: Open University Press.

Tepe, S. (in press). The inclusion-moderation thesis: An overview. In W. R. Thompson (Ed.), The Oxford ency- clopedia of politics. Oxford: Oxford University Press. van Schuur, W. H. (2003). Mokken scale analysis: Between the Guttman scale and parametric item response theory. Political Analysis, 11(2), 139-163.

\section{About the Author}

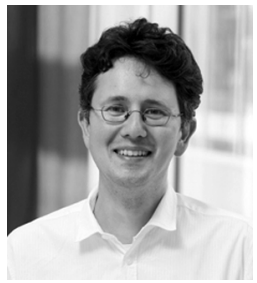

Laurent Bernhard (PhD, University of Zurich) is a Senior Researcher at the Swiss Centre of Expertise in the Social Sciences (FORS), which is hosted by the University of Lausanne. He is currently involved in the Swiss Election Study (Selects) as well as in the VOTO surveys. His main research interests include populism, direct democracy, political communication, and asylum policies. 